\title{
Detection of Hepatitis B Viral Markers in Saliva and Serum of Chronic Carriers in Erbil Governorate
}

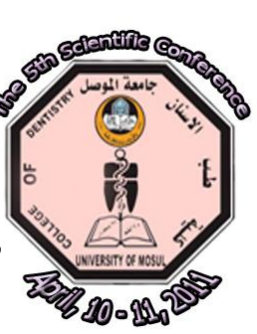

\begin{abstract}
Introduction: Hepatitis B virus is a serious public health problem worldwide and major cause of acute and chronic hepatitis, cirrhosis and hepatocellular carcinoma. The high resistance of HBV to inactivation and its high concentration in blood and other body fluids such as saliva, semen, vaginal secretion, breast milk and tears accounts for its high infectivity. It has been estimated that dental practitioners are three to five times at a higher risk than the general population through the exposure to the oral secretions and blood of potentially infectious patients. Aims of the Study: The overall aim of this study is to investigate the infectivity of saliva of chronic HBV carriers through detection of HBV antigens and their corresponding antibodies and HBV DNA. Materials and Methods: Serum and saliva samples from 65 confirmed chronic hepatitis B virus (HBV) carriers were examined for the presence of HBV markers using enzyme-linked immunosorbent assay (ELISA) and polymerase chain reaction (PCR). Results: Out of the 65 chronic HBV carriers, 17(26\%) were seropositive for hepatitis $\mathrm{B}$ e antigen $(\mathrm{HBeAg}+)$ and 48(74\%) were seronegative for $\mathrm{HBeAg}$ and seropositive for antibody to $\mathrm{HBeAg}(\mathrm{HBeAg}-/ \mathrm{anti}-\mathrm{HBe}+)$. The detection rates of saliva for HBsAg, anti-HBc, $\mathrm{HBeAg}$ and anti-HBe were $55 \%, 65 \%, 53 \%$ and $100 \%$, respectively, to that of serum. The detection rates of HBV DNA for serum and saliva were $90 \%$ and 60\%, respectively. Conclusions: Based on these results we have arrived at the conclusion that saliva of these carriers might be potentially infectious.
\end{abstract}

Prof Dr. Mahmoud Y M Taha $(B V M S, M S c, P h D)^{1}$; Asst Prof Omer Surchi $(\text { MBChB, FICM })^{2}$; Lect Sazan Mwaffaq Abdulaziz $(B S c, M S c, P h D)^{3}$

${ }^{1}$ Department of Dental Basic Sciences, Dentistry College, Mosul University

${ }^{2}$ Department of Oral Diagnosis, College of Dentistry, Hawler Medical University .

${ }^{3}$ Department of Dental Basic Sciences, Dentistry College, Hawler Medical University

Key Words: HBs Ag, saliva, serum, chronic carrier

\section{INTRODUCTION}

E aliva is a mixture of secretions from the salivary glands and transudate from the capillaries beneath the buccal mucosa, the so-called crevicular fluid, that constantly flows from the crevice between the gum margin and teeth. The contents of the crevicular fluid are similar to plasma, and include significant amounts of antibodies ${ }^{(1)}$. It is well known that HBV is found in all body fluids in much lower concentrations than blood. Saliva is considered as a body fluid with moderate HBV concentration ${ }^{(2)}$. Human saliva has been reported as a vector of horizontal transmission of HBV, but its mechanism remains unknown ${ }^{(3)}$. Intraorally, the highest concentration of hepatitis B virus (HBV) is in the gingival sulcus ${ }^{(4)}$. 
Hepatitis B virus is a serious public health problem worldwide and major cause of acute and chronic hepatitis, cirrhosis and hepatocellular carcinoma (HCC). It was estimated that approximately $30 \%$ of the world's population, or about 2 billion people have serological evidence of past or present HBV infection. It was reported that $15-40 \%$ of $\mathrm{HBV}$ infected patients would develop cirrhosis, liver failure or HCC and 500,000 to 1.2 million people die of HBV infection annually ${ }^{(5,6)}$. The high resistance of HBV to inactivation and its high concentration in blood and other body fluids such as saliva, semen, vaginal secretion, breast milk and tears accounts for its high infectivity ${ }^{(7)}$. It has been estimated that dental practitioners are three to five times at a higher risk than the general population through the exposure to the oral secretions and blood of potentially infectious patients ${ }^{(8,9)}$. No such study has been done in Erbil before to investigate the infectivity of saliva in chronic HBV carriers.

\section{Patients}

\section{MATERIALS AND METHODS}

The present study enrolled 65 chronic hepatitis B virus (HBV) carriers who were identified on the basis of their seropositivity for hepatitis B surface antigen (HBsAg) for more than six months after an acute infection and antibody to hepatitis B core antigen (anti-HBc) of IgG class. Of the 65 patients aged from 5 to 70 years, 46 were male and 19 were female.

\section{Sample collection and processing}

Serum and unstimulated whole mixed saliva samples were collected at the same visit from each subject included in the study. The collected samples were stored at $-20^{\circ} \mathrm{C}$ until use for virological and molecular investigations.

\section{Detection of HBV serological markers}

Enzyme-linked immunosorbent assay (ELISA) (Biokit, Spain) was used for the detection of hepatitis B surface antigen ( $\mathrm{HBsAg}$ ), hepatitis B envelope antigen ( $\mathrm{HBeAg}$ ), antibody to $\mathrm{HBeAg}$ (anti-HBe) and antibody to hepatitis B core antigen (anti-HBc) $\mathrm{IgG}$, and polymerase chain reaction (PCR) (Cinnagen, Iran) for HBV DNA in the collected serum and saliva samples.

\section{Statistical analysis}

Statistical analysis (correlation and t-test) was made using Statistical Package for Science Services (SPSS) version 17.0.

\section{RESULLTS}

Serum and saliva samples were collected from 65 patients identified as chronic HBV carriers. The mean \pm SD age of the study group was $39 \pm 14.9$ (range: 5-70 years) comprising 19 females and 46 males. Of the 65 chronic HBV carriers, 17(26\%) were seropositive for hepatitis B e antigen (HBeAg+) and 48(74\%) were seronegative for $\mathrm{HBeAg}$ and seropositive for antibody to $\mathrm{HBeAg}(\mathrm{HBeAg}-/$ anti-HBe+) (Table 1). No HBeAg+ sample was observed among blood donors and thalassaemic patients. Statistical analysis showed a highly significant relation between the studied groups and HBV infection $(\mathrm{P}=0.000)$. A highly significant difference between $\mathrm{HBe} \mathrm{Ag}+$ and $\mathrm{HBeAg}-/$ anti-HBe+ groups for the studied groups $(\mathrm{P}=0.000)$ was recorded, too.

All HBV markers which were tested in serum were retested in saliva samples and the detection rates of saliva were compared to that of serum. The detection rate of $\mathrm{HBsAg}$, anti-HBc, $\mathrm{HBeAg}$ were 55\%, 65\% and 53\%, respectively (Tables 2, 3 and Figure 1). Generally, saliva 
samples obtained from $\mathrm{HBeAg}+$ chronic $\mathrm{HBV}$ carriers had a higher rate of detection than those obtained from $\mathrm{HBeAg}-/$ anti-HBe+.

Table 1: Distribution of chronic HBV carriers according to the studied risk groups and blood donors and $\mathrm{HBeAg}$ status

\begin{tabular}{ccccc}
\hline Group & \multicolumn{2}{c}{ HBeAg+ } & \multicolumn{2}{c}{ HBeAg-/anti-HBe+ } \\
\cline { 2 - 5 } & No. & $\%$ & No. & $\%$ \\
Hemodialysis & 5 & 29.4 & 2 & 4.2 \\
Lymphoma & 4 & 23.5 & 1 & 2.1 \\
Leukemia & 7 & 41.2 & 11 & 22.9 \\
Healthcare workers & 1 & 5.9 & 3 & 6.3 \\
Blood donors & 0 & 0 & 30 & 62.4 \\
Thalassaemia & 0 & 0 & 1 & 2.1 \\
\hline Total & 17 & 100 & 48 & 100 \\
\hline t-test P-value & & $(0.000)^{* *}$ & \\
\hline
\end{tabular}

$\chi^{2} \mathrm{P}$-value for relation $=0.000(\mathrm{HS})$

Table 2: Comparison between serum and saliva in the detection rate of HBsAg and the relation to $\mathrm{HBeAg}$ status

\begin{tabular}{cccccc}
\hline \multirow{2}{*}{ HBeAg status } & & \multicolumn{2}{c}{ HBsAg Positive } & \multicolumn{2}{c}{ HBsAg Negative } \\
\cline { 3 - 6 } & & No. & $\%$ & No. & $\%$ \\
\hline \multirow{2}{*}{ HBeAg+ } & serum & 17 & 100 & 0 & 0 \\
& saliva & 16 & 94.1 & 1 & 5.9 \\
HBeAg-/anti-HBe+ & serum & 48 & 100 & 0 & 0 \\
& saliva & 20 & 41.7 & 28 & 58.3
\end{tabular}

Table 3: Comparison between serum and saliva in the detection rate of anti$\mathrm{HBc}$ and the relation to $\mathrm{HBeAg}$ status

\begin{tabular}{cccccc}
\multirow{2}{*}{ HBeAg status } & & \multicolumn{2}{c}{ Anti-HBc Positive } & Anti-HBc Negative \\
\cline { 3 - 6 } & & No. & $\%$ & No. & $\%$ \\
\hline \multirow{2}{*}{ HBeAg+ } & serum & 17 & 100 & 0 & 0 \\
HBeAg-/anti-HBe+ & saliva & 10 & 58.8 & 7 & 41.2 \\
& serum & 48 & 100 & 0 & 0 \\
$\chi^{2}$ P-value for relation $=0.000($ HS) & & & & 33.3 \\
& &
\end{tabular}




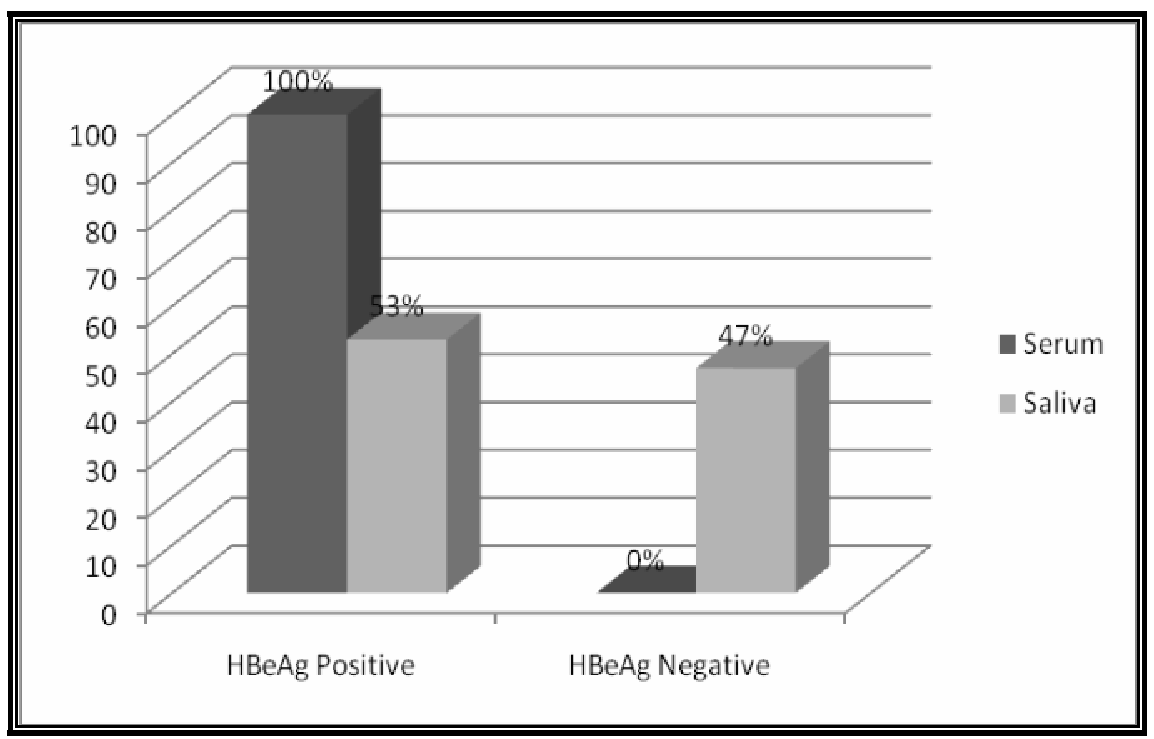

Figure 1: Total percentage of $\mathrm{HBeAg}$ in serum and saliva of $\mathrm{HBeAg}+$ chronic $\mathrm{HBV}$ carriers.

Ten serum and saliva samples from each of $\mathrm{HBeAg}+$ and $\mathrm{HBeAg}-/ \mathrm{anti}-\mathrm{HBe}+$ chronic $\mathrm{HBV}$ carrier groups out of the 65 diagnosed chronic HBV carriers were tested for the presence of the complete HBV particle through the detection of HBV DNA. These samples were amplified using polymerase chain reaction (PCR) technique. Then the PCR product of each tested sample was visualized by running it in an agarose gel electrophoresis as shown in Figures (2 and 3). The presence of a DNA fragment at the same position of the 353bp positive control fragment indicates a positive sample for HBV DNA.

Serum and saliva samples obtained from HBeAg+ group had significantly higher rates of detection (100\% and $70 \%$ respectively) than those obtained from $\mathrm{HBeAg}-/ \mathrm{anti}-\mathrm{HBe}+(80 \%$ and $50 \%$ respectively) group $(\mathrm{P}<0.05)$ with a total detection rates of $90 \%$ and $60 \%$ for serum and saliva, respectively (Table 4, Figure 4).

\# Only 10 serum and 10 saliva samples were tested from each group

\section{DISCUSSION}

The worldwide burden of hepatitis B mandates accurate and timely diagnosis of patients infected with hepatitis B virus (HBV). Serological and nucleic acid testing are critical to determine patient's infectivity and immune status, as well as providing data that contributes to a better understanding of the natural history and epidemiology of the disease ${ }^{10}$.

The results recorded 48(74\%) HBeAg-/anti-HBe+ and 17(26\%) HBeAg+ chronic HBV carriers. Higher prevalence rate of $\mathrm{HBeAg}-/ \mathrm{anti}-\mathrm{HBe}+$ over $\mathrm{HBeAg}+$ groups were also recorded by Lindh et al. ${ }^{(11)}$ and Elefsiniotics et al. ${ }^{(12)}$. Patients with Leukemia and lymphoma comprise $65 \%$ of the HBeAg+ group. Reactivation of HBV infection is common among patients with leukemia and solid tumors in whom the immune system is supressed due to the cytotoxic effects of chemotherapy and radiotherapy ${ }^{(13-15)}$.

In this study, all HBV markers tested in serum were retested in saliva samples and the detection rates of saliva were compared to that of serum. Table (2) shows a comparison between 
serum and saliva in the detection rate of $\mathrm{HBsAg}$ and the relation to $\mathrm{HBeAg}$ status. Saliva samples obtained from HBeAg+ chronic HBV carriers had a higher rate of detection $(94.1 \%)$ than those obtained from $\mathrm{HBeAg}-$ /anti-HBe+ chronic HBV carriers (41.7\%). Statistical analysis showed a highly significant relation between salivary HBsAg and HBeAg in serum. Nearly, the same results have been observed by Zhevachevsky et al. ${ }^{(16)}$ for salivary detection rate in $\mathrm{HBeAg}+$ and $\mathrm{HBeAg}-/$ anti-HBe+ groups (100\% and $42 \%$, respectively).

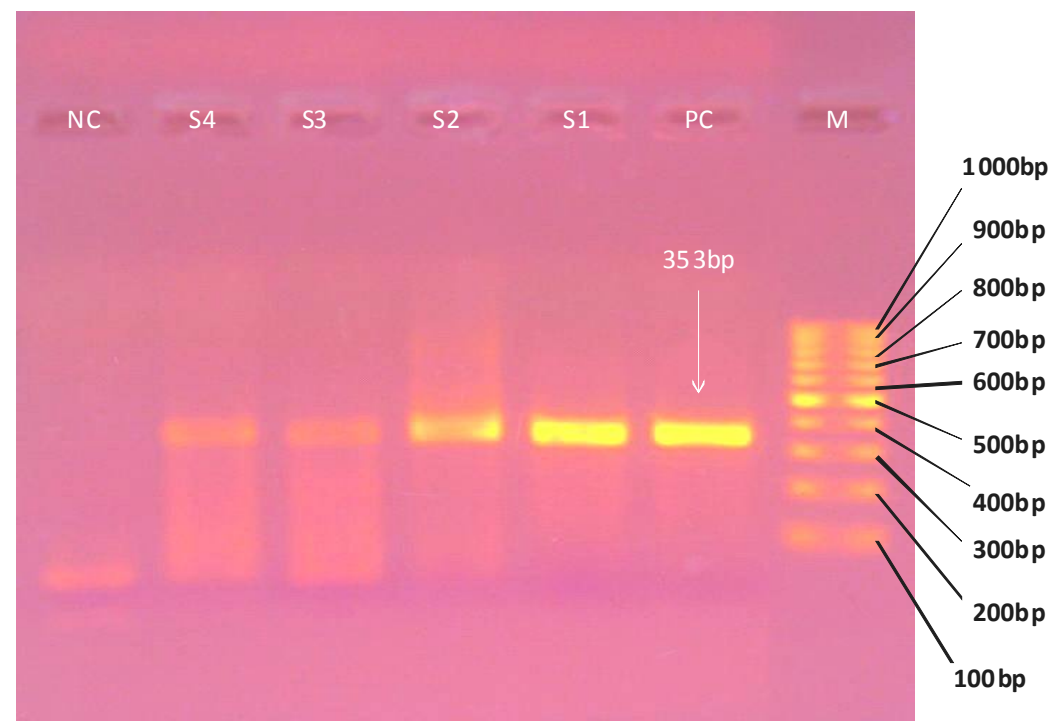

(a)

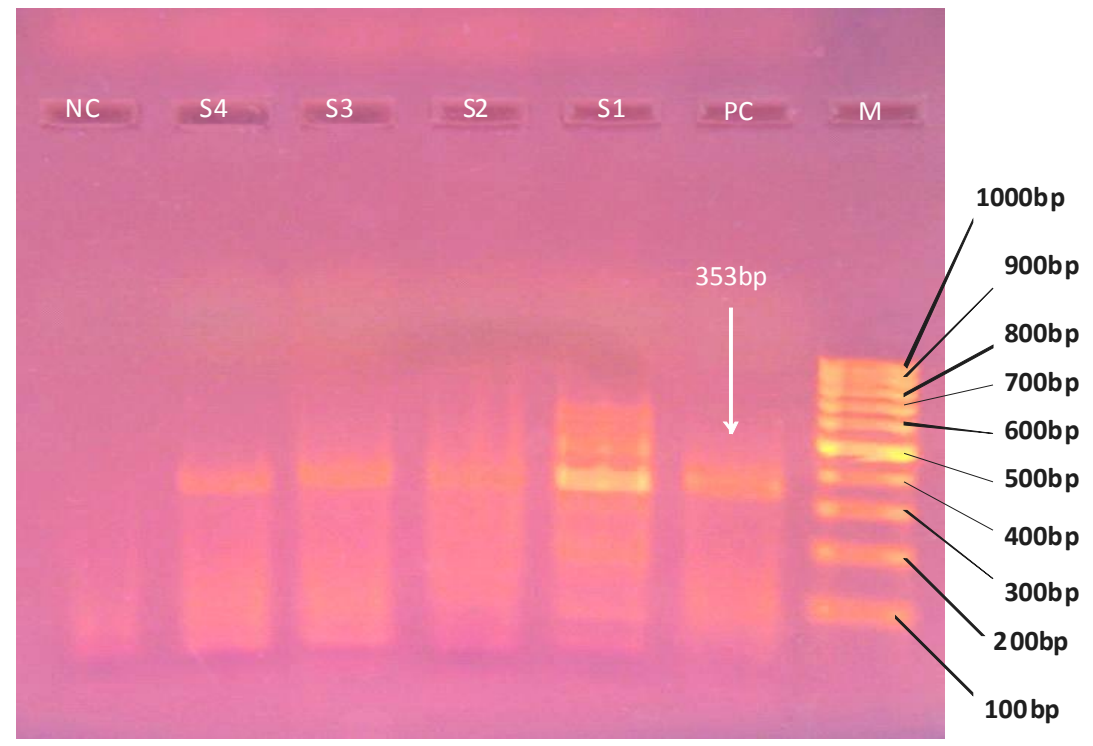

(b)

Figure 2: Agarose gel electrophoresis of the amplified PCR products of serum $+/$ saliva + samples. (a) serum (b) saliva. M=DNA marker 100-1000bp, PC=Positive control, S1-4=Samples number 1, 2, 3 and 4, $\mathrm{NC}=$ Negative control. 


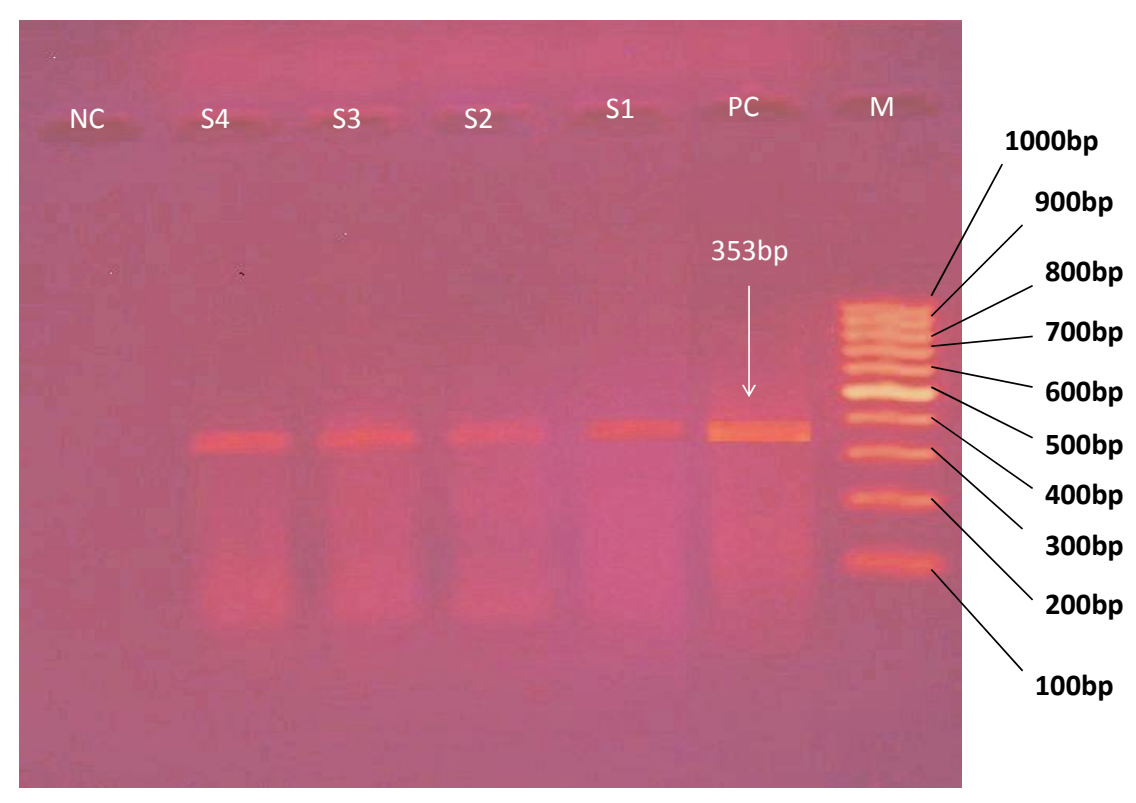

(a)

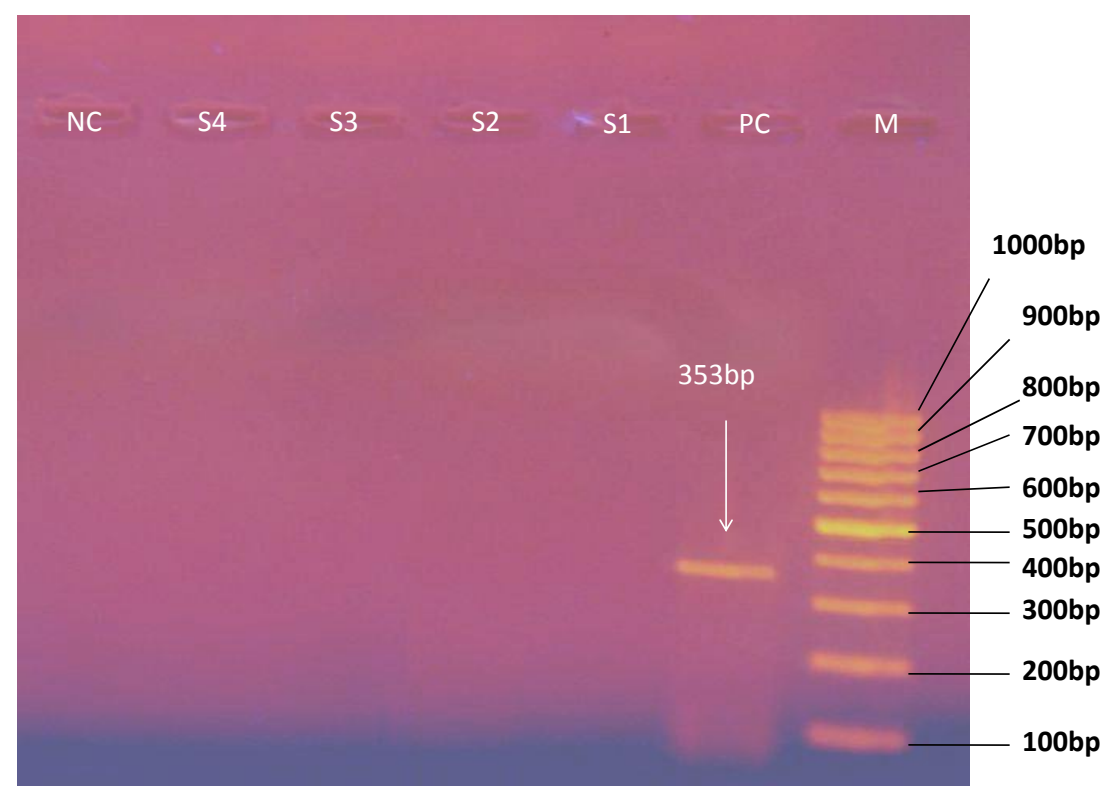

(b)

Figure 3: Agarose gel electrophoresis of the amplified PCR products of serum $+/$ saliva samples. (a) serum (b) saliva. M=DNA marker 100-1000bp, PC=Positive control, S1-4=Samples number 1, 2, 3 and 4, $\mathrm{NC}=$ Negative control.

Journal of the $5^{\text {th }}$ Scientific Conference of Dentistry College, Apr. 2011 
Table 4: Comparison between serum and saliva in the detection rate of HBV DNA and the relation to HBeAg status

\begin{tabular}{cccccc}
\hline \multirow{2}{*}{ HBeAg status } & & \multicolumn{2}{c}{ HBV DNA Positive } & HBV DNA Negative \\
\cline { 2 - 6 } & & No. & $\%$ & No. & $\%$ \\
\hline \multirow{2}{*}{ HBeAg+ } & serum & 10 & 100 & 0 & 0 \\
& saliva & 7 & 70 & 3 & 30 \\
HBeAg-/anti-HBe+ & serum & 8 & 80 & 2 & 20 \\
& saliva & 5 & 50 & 5 & 50 \\
\hline t-test P-value & & & $(0.000) * *$ & & \\
\hline ** Highly Significant (HS) (P< $<.01)$ & & & &
\end{tabular}

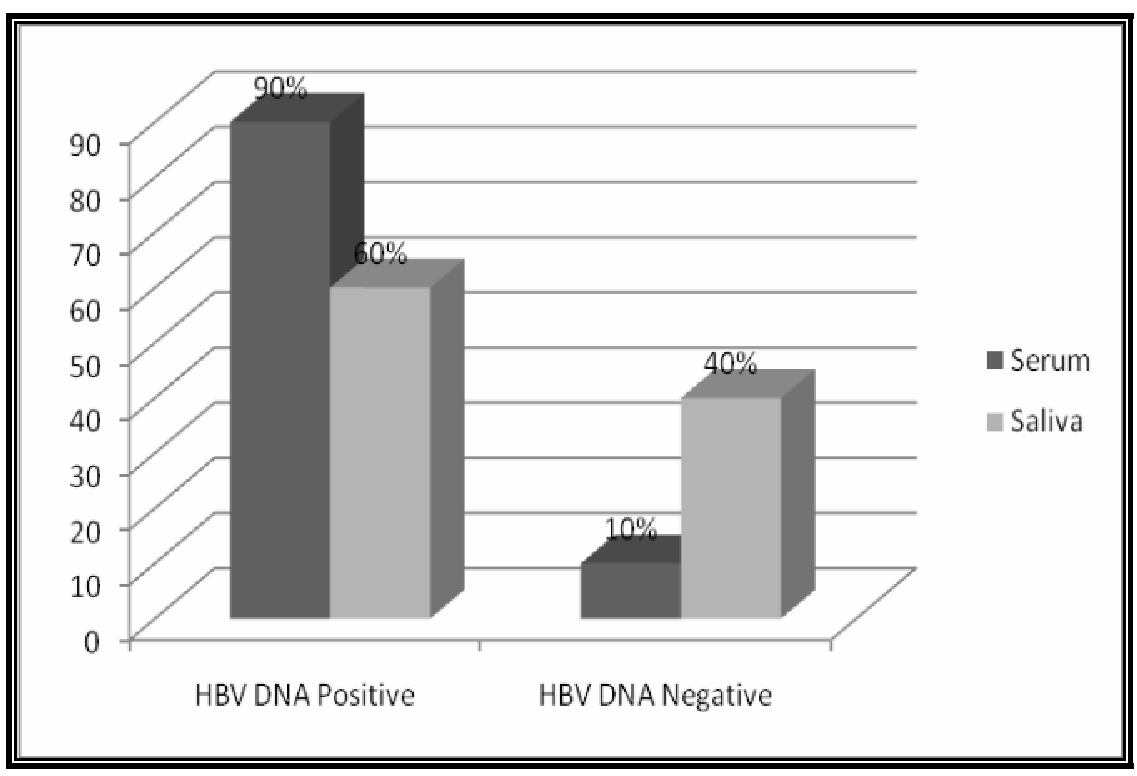

Figure 4: Total percentage of HBV DNA detection in serum and saliva of chronic HBV carriers.

Saliva samples obtained from HBeAg+ chronic HBV carriers had a lower rate of detection (58.8\%) than those obtained from HBeAg-/anti-HBe+ chronic HBV carriers $(66.7 \%)$ with a total detection rate of $65 \%$ when compared to the detection rate of serum. This detection rate is higher than the recorded rate $(43 \%)$ of Nokes et al. ${ }^{(17)}$.

Regarding salivary $\mathrm{HBeAg}$ detection rate in $\mathrm{HBeAg}+$ chronic $\mathrm{HBV}$ carriers, saliva had relatively a low rate of detection (53\%) when compared to serum (Figure 1). Such result might be related to HBV activity in the liver. In a study on 118 chronic HBV carriers and 87 patients 
with liver cirrhosis, it was found that the HBeAg values in patients with high HBV DNA level were significantly higher than those in patients with low HBV DNA level ${ }^{(18)}$.

In the garose gel electrophoresis photos, the presence of a DNA band at the same position of the 353bp positive control band indicates a positive sample for HBV DNA. Statistical analysis showed a highly significant relation between HBV DNA and HBeAg in serum. The same results showed that serum and saliva samples obtained from $\mathrm{HBeAg}+$ chronic $\mathrm{HBV}$ carriers had a significantly higher HBV DNA detection rates (100\% and $70 \%$ respectively) than those obtained from $\mathrm{HBeAg}-/$ anti-HBe+ chronic $\mathrm{HBV}$ carriers $(80 \%$ and $50 \%$ respectively). Serum detection rate is in accordance with that observed by Ballard and Boxall ${ }^{(19)}(98 \%)$ and Jen et al. ${ }^{(20)}$ (97\%) and much higher than a $63 \%$ detection rate recorded by Rodrigues et al. . Regarding $\mathrm{HBeAg}+$ group, the detection rate of HBV DNA in saliva is higher than what recorded by Zhevachevsky et al. ${ }^{(16)}$ (46\%). HBeAg-/anti-HBe+ chronic HBV carriers are usually considered to have nonreplicative HBV infection with low or undetectable HBV DNA in their sera. The high percentage of positive serum and saliva results ( $80 \%$ and $50 \%$ respectively) of this group might be due to high sensitivity of $\mathrm{HBV}$-specific primers that could detect even very low concentrations of $\mathrm{HBV}$ DNA in the tested sample. This is well documented in a study done by Lee $e{ }^{a l}{ }^{(21)}$ in which he could not detect HBV DNA from the tested serum and saliva samples due to many more nonspecific bands that were produced from saliva samples than from serum samples. He attributed this to the low specificity of PCR primers. Another possible interpretation of this result is that infection might be caused by a mutant form of $\mathrm{HBV}$ that does not produce $\mathrm{HBeAg}$ due to mutation in the precore or core promoter region, but anti-HBe is produced. Infection with these variants is associated with active viral replication, but not to that extent of $\mathrm{HBeAg}+$ infections. In a review study on the worldwide epidemiology of HBeAg-negative chronic hepatitis $B$ and associated precore and core promoter variants, it was found that the median prevalence of core promoter variant was $92 \%$ in the Mediterranean, $50 \%$ in Asian Pacific and $24 \%$ in the USA ${ }^{(22)}$. A study of hepatitis B virus precore mutant among Iraqi chronic hepatitis B patients treated with interferon alpha reported a $100 \%$ HBV detection rate in sera of patients with HBV precore variants ${ }^{(23)}$. The total percentage of HBV detection rate in serum and saliva of chronic HBV carriers was $90 \%$ and $60 \%$, respectively. Nearly, similar results was observed by Noppornpanth et al. ${ }^{(24)}$ who reported a $91 \%$ and $48 \%$ detection rates for serum and saliva, respectively.

\section{CONCLUSIONS}

In conclusion, our observations have emphasized the risk of saliva from all HBsAgpositive patients to be potentially infectious. Further investigations are required to confirm the infectivity of human saliva, as well as determine the characteristics of HBV present in saliva.

\section{REFERENCES}

1. Madar, R., Straka, S. and Baska, T. Detection of antibodies in saliva - an effective auxiliary method in surveillance of infectious diseases. Bratisl Lek Listy, (2002); 103(1): 38-41.

2. Samaranayake, L.P.; Jones, B.M. and Scully, C. Essential microbiology for dentistry. $2^{\text {nd }}$ ed.: Churchill Livingstone. (2002); P: 187-95.

3. Marie-Cardine, A.; Mouterde, O.; Dubuisson, S.; Buffet-Janvresse, C. and Mallet, E.. Salivary transmission in an intrafamilial cluster of hepatitis B. Journal of Pediatric Gastroenterology and Nutrition, (2002); 34(2): 227-30.

4. Krasteva, A.; Panov, V.1.; Garova, M.; Velikova, R.; Kisselova, A. and Krastev, Z . Hepatitis B and C in dentistry. Journal of International Medical Association “Bulgaria”, (2008); book 2: 38-40. 
5. Yan, J.M.; Govindarajan, S.; Arakawa, K. and Yu, M.C. Synergism of alcohol, diabetes, and viral hepatitis on the risk of hepatocellular carcinoma in blacks and whites in the US. Cancer, (2005); 101(5): 1009-17.

6. Alavian, S-M; Moosavi, S-H; Mousavi, S-H; Azizi, B. and Akbari, H. Study of admission rate of hepatitis B surface antigen positive patients in 50 dentistry centers in Tehran (spring 2008). Hepatitis Monthly(2008); 8(1): 67-9.

7. Wray, D.; Lowe, G.D.O.; Dagg, J.H.; Felix, D.H. and Skully, C. Textbook of general and oral medicine. $1^{\text {st }}$ ed. Edinburgh: Churchill Livingstone. (2001); P: 21-32.

8. Sonis, S.T.; Fazio, R.C. and Fang, L.. Priciples and practice of oral medicine. $2^{\text {nd }}$ ed. Philadelphia: W. B. Saunders. (1995); P: 213-4.

9. Ghom, A.G. Textbook of oral medicine. $1^{\text {st }}$ ed. New Delhi: Jaypee Brothers. (2005); P: 702-4.

10. Gish, R.G. and Locarnini, S.A. Chronic hepatitis B: current testing strategies. Clinical Gastroenterology and hepatology, (2006); 4(6): 666-76.

11. Lindh, M.; Horal, P.; Dhillon, A.P. and Norkrans, G.. Hepatitis B virus DNA levels, precore mutations, genotypes and histological activity in chronic hepatitis B. Journal of Viral Hepatitis, (2000); 7(4): 258-67.

12. Elefsiniotics, I.S.; Glynou, I.; Pantazis, K.D.; Fotos, N.V.; Magaziotou, I. and Kada, H.. Prevalence of chronic HBV infection among 13,581 women at reproductive age in Greece. A prospective single center study. Journal of Clinical Virology, (2005); 32(2): 179-80.

13. Marusawa, H.; Imoto, S.; Ueda, Y. and Chiba, T. Reactivation of latently infected hepatitis B core antigen. (2001); 36(9): 633-6.

14. Celkan, T.; Apak, H.; Ozkan, A.; Bas, V.; Karaman, S.; Yuksel, L. and Yildiz, I.. Hepatitis B infection serologies and vaccination responses in ALL patients after treatment. Turkish Journal of Immunology, (2005); 10(1): 19-22.

15. Dehghani, M. Acute hepatitis B in a patient with antibody to hepatitis B surface antigen who was receiving chemotherapy for acute myelogenous leukemia with cytarabine and daunorubicin. Shiraz E-Medical Journal, (2008); 9(1): 42-4. Available from: http://semj.sums.ac.ir/vol9/jan2008/hep.htm.

16. Zhevachevsky, N.G.; Nomokonova, N.Y.; Beklemishev, A.B. and Belvo, G.F. Dynamic study of HBsAg and $\mathrm{HBeAg}$ in saliva samples from patients with hepatitis B infection: diagnostic and epidemiological significance. Journal of Medical Virology, (2000); 61(4): 433-8.

17. Nokes, D.J.; Enquelassie, F.; Nigatu, W.; Vyse, A.J.; Cohen, B.J.; Brown, D.W.J. and Cutts, F.T.. Has oral fluid the potential to replace serum for the evaluation of population immunity levels? A study of measles, rubella and hepatitis B in rural Ethiopia. Bulletin of the World Health Organization. (2001); 79(7): 588-95.

18. Xie, Y.; Zhao, H.; Dai, W-S. and Xu, D-Z. HBV DNA level and antigen concentration in elevating liver damage of patients with chronic hepatitis B. Hepatobiliary and Pancreatic Diseases International, (2003); 2(3): 418-22.

19. Ballard, A.L. and Boxall, E.H.. Assessing the infectivity of hepatitis B carriers. Communicable Diseases and Public Health, (1999); 2(3): 178-83.

20. Jen, C-M.; Young, K-C.; Cheng, P-N.; Kao, A-W and Chang, T-T. Limitations and improvements of the quantiplex branched-DNA assay in hepatitis B virus-infected patients receiving lamivudine. Journal of Virological Methods, (2001); 96(2): 203-10.

21. Lee, S-A, Yoo, S.Y.; Kay, K-S and Kook, J-K. Detection of hepatitis B virus and Mycobacterium tuberculosis in Korean dental patients. The Journal of Microbiology, (2004); 42(3): 239-42.

22. Funk, M.L.; Rosenberg, D.M. and Lok, A.S.F. World-wide epidemiology of HBeAg-negative chronic hepatitis B and associated precore and core promoter variants. Journal of Viral Hepatitis, (2002); 9(1): 52-61.

23. Al-Jaaf, A.M.A.. A study of hepatitis B virus precore mutants among Iraqi chronic hepatitis B patients treated with interferon alfa. M.Sc. thesis. University of Baghdad, Genetic Engineering and Biotechnology Institute for Postgraduate studies. Iraq. (2006).

24. Noppornpanth, S.; Sathirapongsasuti, N.; Chongsrisawat, V. and Poovorawan, Y.. Detection of HBsAg and HBV DNA in serum and saliva of HBV carriers. Southeast Asian Journal of Tropical Medicine \& Public Health, (2000); 31(2): 412-21. 